\title{
EDITORIAL: AIMS AND ENDS IN EDUCATION
}

\author{
CHRISTOPH TESCHERS \\ Christoph.teschers@ canterbury.ac.nz \\ University of Canterbury \\ SHIRLEY HARRIS \\ Shirley.harris@ucic.ac.nz \\ UC International College
}

"Education is not a preparation for life, but is life itself." - John Dewey

As technological advancement develops at an exponential rate, we are told that the Western world is entering the Fourth Industrial Revolution. This encapsulates a shift, it is claimed, from simple digitization of the Third Industrial Revolution to one that embraces innovation and change due to a combination of technologies, including Artifical Intelligence and biotechnological development (Klaus Schwaab, 2015, Chairman of the World Economic Forum). In this new world, according to Schwab, neoliberalism will be dead, new fears will rise, our privacy as individuals will be increasingly under threat, and we will be required to redefine our moral and ethical boundaries. In fact, he believes, we may even have to renegotiate what it means to be human beings. Such claims raise important questions for the future of education.

Within a New Zealand context, conflicting discourses are apparent. Despite an emerging international trend proclaiming the imminent death of neoliberal economics (Buckup, 2017; Schwaab, 2015; see also Nesta Devine's article in this issue), the ongoing influence of a neoliberalism discourse in education continues through the promotion of marketization economics in New Zealand. The national government, at the time of this editorial being written, has proposed a new Tertiary Education Bill (Goldsmith, 2017) whereby public and private tertiary providers would be equally funded in future, opening tertiary education to further marketization despite strong concerns of the impact of such policies on the diversity of tertiary education and locally run programmes that are supporting local communities.

In contrast, "Future-oriented" educational research is being funded by the Ministry of Education, in a bid to keep abreast of the "new revolution" upon us. Questions are being raised in respect to current teaching and learning pedagogy and 
the role of education itself as we find ourselves progressing into the Knowledge Age of the $21^{\text {st }}$ Century. According to recent research undertaken by NZCER on behalf of the government, "reproducing existing knowledge can no longer be education's core goal" (Bolstad, Gilbert, McDowall, Bull, Boyd \& Hipkins, 2012, p. 4), as we are moving into an age where the knowledge base of a society can no longer be pre-determined. Instead, it will be characterised by the creation of knowledge as and when required.

Such claims, if hold true, require us to take a step back and re-evaluate education as we know it, its underpinning values as well as its fundamental purpose (see, for example, Freeman-Moir's article on the work of Dewey). We need to ask, what impact will these inexhaustible changes in technological development have for education as a discipline? Is it a given that education at its very essence needs to respond and change to societal developments, or is there an inherent aim within the realms of education that transcends current fast moving scientific, technological and social developments? - If we are entering a new age of educational thinking, it is timely to begin by reappraising the aims and ends of education, both historically and current, as Dewey stated that educational aims are many, local and contemporary:

We have indicated that since general aims are but prospective points of view from which to survey the existing conditions and estimate their possibilities, we might have any number of them, all consistent with one another. As matter of fact, a large number have been stated at different times, all having great local value. For the statement of aim is a matter of emphasis at a given time. (Dewey, 1916/2001, p. 116)

However, despite this contemporary and changing approach to educational aims, he also indicates a possible larger end of education: "[e]ach generation is inclined to educate its young so as to get along in the present world instead of with a view to the proper end of education: the promotion of the best possible realization of humanity as humanity" (p. 100).

This special edition of Knowledge Culture begins to address the question of aims and ends in education from a range of perspectives, drawing, among others, upon the teachings of John Dewey, to explore the purpose of education as we know it, its ongoing value and how it might evolve as we move forward into the future. Dewey's work provides one basis for understanding education itself, but also emphasises the critical links between the individual and society.

With this in mind, the opening article in this special edition is the keynote address Aims as experience by John Freeman-Moir, presented to the NZARE Educational Ideas and Education Policy Special Interest Groups' Conference on Aims and Ends in Education, at the University of Canterbury, New Zealand, 29 August 2016. Freeman-Moir sets the scene for the special edition by exploring Dewey's pragmatism in relation to the aims and ends of education as we know it today. With a focus on the interplay between means and ends as they relate to 
human action, Freeman-Moir discusses the implications of Dewey's thinking in respect to their symbiotic nature. He challenges the reader to consider, not what is an aim, but rather "when and how is an aim," thus identifying the importance of contextualising the question when giving it due consideration. When relating the conversation to education, Freeman-Moir argues that the aim of education is to, in fact, enable the continuity of education.

Continuing the flow of ideas from the work of Dewey, the next article, The heART of the matter by Locke, Gerlich, Godfery, Fraser, Robertson and Roberts, traverses the Deweyan influence of social democracy within the New Zealand education system across time to the current regime of neoliberalism. Located within a context of Art Education, the purpose of the article is to provide an array of perspectives in a bid to provoke the reader to "call for the reassessment of educational focus and aims" within today's political climate. We are reminded of Peter Fraser's (New Zealand's $24^{\text {th }}$ Prime Minister) legacy for education, in an attempt to re-position the discourse away from a neoliberal agenda to one that places the aims and ends of education back at the centre for achieving a democratic society.

The next three articles of this special issue then take a turn to reconsider aims and ends of education from different angles, taking a holistic, future oriented perspective.

The first article here is a call to Humanizing secondary school context: learning from Aotearoa New Zealand and Peru by Fickel, Nieto Angel, Macfarlane and Macfarlane, drawing on preliminary findings from an ongoing cross-cultural study in three secondary schools in Peru and New Zealand. The article highlights an alternative approach to "enacting a 'holistic' and 'humanising' education," drawing on student, teacher and principal voices to highlight "philosophies of care, restoration and forgiveness," in relation to educational aims. Indigenous perspectives from both counties are incorporated to broaden the horizon of educational aims and ends beyond common "Western" understandings.

Teschers then advocates for A beautiful life as an end of education, distinguishing between short-lived, contextual aims in education versus long term, overarching and intrinsic end(s) of education. Teschers draws on the German notion of Bildung in an attempt to consolidate Dewey's and R. S. Peters' perspectives on broad educational ends with his holistic approach to education based on the philosophical concept of the art of living.

Finally in this section, Gilbert adopts a post structuralist approach to critique science education in its current form. She claims in Back to the future? Aims and ends for future-oriented science education policy - The New Zealand Context that there is now an incongruence between science education and science in schools, as current policy continues to draw on outdated philosophical understandings of science. She proposes that it is time for a "re-purposing" particularly of intellectual development and uses the work of Dewey and Whitehead to advance a future- 
focused approach to science education policy that embraces the changing complexity and multiplicity of science in practice.

The issue then concludes with Devine's article Aims of education in a postneoliberal context, in which a Foucaultian genealogical approach is taken to respond to the inadequacy of "current official aims for education" in regard to student needs in our current rapidly changing world. Devine reflects on neoliberal agendas and educational policy in the New Zealand context, exploring the question of which social and educational direction might come after the economic and subsequent political downfall of neoliberalism as prevalent ideology. It is not as simple as a fallback to the Keynesian welfare state model, Devine argues, but new answers have to found.

This closes the circle of a reflection on educational aims and ends from past to present to future in New Zealand and internationally, presenting a range of perspectives to encourage a wider discussion of education's aims and ends as we move forward.

\section{REFERENCES}

Bolstad, R., Gilbert, J., McDowall, S., Bull, A., Boyd, S., \& Hipkins, R. (2012). Supporting future-oriented learning and teaching: A New Zealand perspective. Wellington, New Zealand: Ministry of Education.

Buckup, S. (2017). The end of neoliberalism? World Economic Forum, 17 July. Retrieved on 12.09.17 from https://www.weforum.org/agenda/ 2017/07/this-is-what-the-future-ofeconomic-liberalism-looks-like-its-time-to-rethink-it/

Dewey, J. (1916/2001). Democracy and education. Electronic Classics Series. Hazleton, PA: The Pennsylvania State University.

Goldsmith, P. (2017). Education (Tertiary Education and other matters) amendment bill. Wellington, New Zealand. Retrieved on 04.09.2017 from http://www.legislation.govt. nz/bill/government/2017/0210/latest/DLM7044714.html

Schwaab, K. (2015). The fourth industrial revolution: what it means, how to respond. Foreign Affairs, 12 Dec. Retrieved 12.09.17 from https://www.foreignaffairs.com/ articles/2015-12-12/fourth-industrial-revolution

Christoph Teschers is faculty member at the College of Education, Health and Human Development, University of Canterbury, New Zealand. He has published several articles and book chapters and is author of Education and Schmid's Art of Living (2018). Taking an interdisciplinary approach, he is mainly interested in the relationship between people's wellbeing, the philosophical notion of the art of living and educational theory and practice. Other areas of interest include philosophy for children, positive psychology, inclusive education, ethics and social justice.

Shirley Harris is the Academic Coordinator at UC International College, University of Canterbury. She has extensive experience working across all sectors in the education system in a variety of roles. A university lecturer for over a decade, Shirley subsequently ran a private educational consultancy engaging in community-based research projects at 
both the national and regional level. More recently, she has held leadership positions in research, curriculum and teaching and learning development at tertiary level. Shirley was the co-editor for the Journal of Educational Leadership, Policy and Practice (2015-17). Her research interests are leadership, social justice, diversity and teaching pedagogy. 